ISSN: 1979-7362

\title{
Dampak Pemompaan Air Tanah Terhadap Profil Resistivitas Lapisan Tanah Di Lahan Persawahan
}

\author{
Trialita Aprilia ${ }^{1}$, Mahmud Achmad ${ }^{1}$ dan Ahmad Munir ${ }^{1}$ \\ 1)Program Studi Teknik Pertanian, Universitas Hasanuddin Makassar
}

\begin{abstract}
ABSTRAK
Air tanah adalah air yang berada di bawah permukaan tanah pada wilayah jenuh atau semua poripori dan ruang antar partikel tanah jenuh berisi air, yang terdapat pada bagian atas disebut water table dan bagian bawah disebut ground water. Konsep lain mengatakan, bahwa air tanah terdiri atas dua zona, yaitu zona tidak jenuh (unsaturated zone) dan zona jenuh (saturated zone) atau ground water. Adapun tujuan dari penelitian ini yaitu untuk menentukan nilai resistivitas atau nilai tahanan jenis batuan lapisan bawah permukaan tanah sepanjang lintasan pengambilan data sebelum dan sesudah pemompaan dengan menggunakan geolistrik. Dalam metode penelitian terdapat beberapa tahap, dimana tahap pertama yaitu pengumpulan data dimana data yang dikumpul adalah data skunder, tahap kedua yaitu pengukuran resistivitas dimana pengukuran resistivitas ini menggunakan alat geolistrik multichanel, dan tahap ketiga yaitu pengolahan data dimana terdapat dua langkah yang pertama pengolahan data excel dan langkah kedua pengolahan data software res2dinv. Berdasarkan hasil pengolahan data didapatkan nilai pada pengukuran 1 lintasan 1 sebelum dipompa nilainya dari 1,53 - $215 \Omega \mathrm{m}$, lintasan 1 sesudah pompa 1,20 - 29,5 $\Omega \mathrm{m}$, kemudian pada lintasan 2 sebelum pompa nilainya 1,13 - $206 \Omega \mathrm{m}$, lintasan 2 sesudah pompa $1,22-41,2 \Omega \mathrm{m}$, pada pengukuran 2 , lintasan 1 sebelum pompa nilainya $1,07-203 \Omega$, lintasan 1 sesudah pompa nilainya $0,599-84,9 \Omega \mathrm{m}$, kemudian pada lintasan 2 sebelum pompa $0,413-83,3 \Omega \mathrm{m}$, pada lintasan 2 sesudah pompa nilainya $0,528-49,0 \Omega \mathrm{m}$, pada pengukuran 3 lintasan 1 sebelum pompa nilainya $0,837-202 \Omega \mathrm{m}$, lintasan 1 sesudah pompa nilainya $0,454-38,3 \Omega \mathrm{m}$, kemudian pada lintasan 2 sebelum pompa nilainya 1,11 - $157 \Omega \mathrm{m}$, pada lintasan 2 sesudah pompa nilainya $0,737-61,7 \Omega \mathrm{m}$. Dari hasil tersebut dapat disimpulkan bahwah keberadaan clay berada direntang nilai resistivitas 1-100 $\Omega \mathrm{m}$, keberadaan material air tanah berada di rentang nilai resistivitas sangat rendah yaitu 0,5-300 $\Omega \mathrm{m}$, dan keberadaan material alluvial berada di rentang nilai resistivitas dari 10-800 $\Omega \mathrm{m}$.
\end{abstract}

Kata kunci: Air tanah, Geolistrik, Res2dinv.

\section{PENDAHULUAN}

\section{Latar Belakang}

Air tanah adalah air yang berada di bawah permukaan tanah pada wilayah jenuh atau semua pori-pori dan ruang antar partikel tanah jenuh berisi air, yang terdapat pada bagian atas disebut water table dan bagian bawah disebut ground water. Konsep lain mengatakan, bahwa air tanah terdiri atas dua zona, yaitu zona tidak jenuh (unsaturated zone) dan zona jenuh (saturated zone) atau ground water. Pada zona tidak jenuh terdapat air tanah (soilwater) dimana tanaman dapat memanfaatkannya, tetapi bisa hilang karena evaporasi. Di atas zona jenuh terdapat water table, dan air yang berada pada zona tidak jenuh tidak dapat diambil (dipompa) karena ditahan oleh gaya kapiler.

Saat ini pertanian di Kelurahan Bajeng sudah banyak yang menggunakan sumur pantek untuk mengairi lahan pertaniannya. Sumur pantek atau yang sering disebut sumur bor karena cara pembuatannya dengan cara mengebor tanah dengan kedalaman biasanya 9 sampai 40 meter hingga menemukan sumber air dari dalam tanah. Pembuatan sumur pantek merupakan salah satu cara mengambil air dari dalam tanah untuk mengairi lahan pertanian ketika kekeringan atau curah hujan di Kelurahan Bajeng menurun. Keadaan air termasuk air tanah di Indonesia telah mengalami degradasi dengan imbangan air yang buruk. Untuk itu juga 
diperlukan berbagai usaha-usaha atau cara pencegahannya. Pengambilan air tanah dengan cara pemompaan yang berlebihan (overpumping) atau melebihi serahan aman (safe yield) telah terbukti menimbulkan dampak negatif terhadap kondisi dan lingkungan air tanah. Dampak negatif karena pengambilan air tanah yang melebihi serahan aman diawali dengan penurunan muka air tanah secara terus menerus hingga melebihi batas muka air tanah aman.

Berdasarkan uraian tersebut, maka penelitian mengenai pengaruh pemompaan air tanah terhadap air tanah dangkal dapat dilakukan pada lahan persawahan di Kabupaten Takalar, seberapa besar perubahan pada gambaran tinggi muka air tanah sebelum pemompaan dan sesudah pemompaan pada lokasi Kelurahan Bajeng, Kecamatan Patalasang, Kabupaten Takalar dengan menggunakan metode geolistrik

\section{Tujuan dan kegunaan}

Tujuan dari penelitian ini yaitu untuk menentukan nilai resistivitas atau nilai tanahan jenis batuan lapisan bawah permukaan tanah sepanjang lintasan pengambilan data sebelum dan sesudah pemompaan dengan menggunakan geolistrik.

Kegunaan dari penelitian ini yaitu untuk mengetahui material-material bumi atau struktur lapisan bawah permukaan tanah dan keberadaan potensi air tanah sebelum dan sesudah pemompaan.

\section{METODOLOGI PENELITIAN}

\section{Waktu \& Tempat}

Penelitian dampak pemompaan air tanah terhadap profil resistivitas lapisan tanah di lahan persawahan dilaksanakan pada Bulan Mei 2017 di Kelurahan Bajeng, Kecamatan Patalasang, Kabupaten Takalar

\section{Peralatan Dan Perlengkapan Penelitian \\ Adapun alat dan bahan yang} digunakan dalam pengambilan data geolistrik multi channel (2D) dilapangan sebagai berikut:

a. Alat set alat Resistivity Meter S-Field Multichannel.

b. 11 elektroda.

c. Laptop dan Software Geores.

d. Kabel elektroda.

e. Aki 12 volt.

f. Konektor.

g. Meteran.

h. Palu.

i. Kabel laba-laba.

j. Alat tulis-menulis.

k. Payung,

Sedangkan perlengkapan tambahan bersifat menujang kelancaran dalam pendugaan meliputi:

a. GPS merk garmin digunakan untuk mengetahui posisi daerah.

b. Peta Geologi.

c. Alat tulis untuk mencatat nilai a, V, I

\section{Metode Penelitian}

Metode yang digunakan adalah metode geolistrik Multi Channel (2D). Konfigurasi yang dipakai adalah konfigurasi wenner-sclumberger. Kegiatan penelitian ini meliputi survey tempat, pengumpulan data, pengukuran langsung, serta pengolahan data.

1. Pengumpulan Data

Dalam penelitian dampak pemompaan air tanah terhadap profil resistivitas lapisan tanah di lahan persawahan data yang dibutuhkan yaitu data skunder meliputi:

a. Peta Kabupaten Takalar

b. Peta Geologi Lokasi Penelitian.

2. Pengukuran Resistivitas.

Prosedur pengukuran pada alat geolistrik Multi Channel (2D) yaitu:

a. Menyiapkan alat yang akan digunakan untuk akuisisi data.

b. Pada pengukuran sebelum dipompa, pada lintasan pertama bentangkan meteran sejauh 100 meter diatas lahan persawahan, kemudian memasang elektroda dengan menancapkan eletroda di atas lahan sawah yang sudah diukur dengan spasi 10 meter antar 
ISSN: 1979-7362

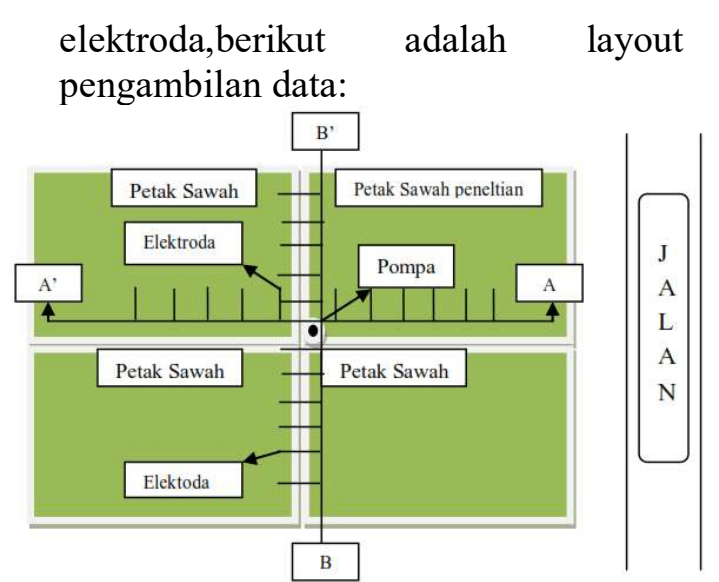

Gambar 1. Layout Pengukuran

c. Memasang kabel pada elekroda pada elektroda dan hubungkan dengan konektor kabel.

d. Memasang aki pada konektor aki.

e. Menghubungkan konektor pada alat.

f. Memasang konektor PC ke alat lalu nyalakan PC.

g. Memastikan kedua battery masih dalam kondisi yang cukup.

h. Membuka Software Geores pada PC.

i. Mengecek apakah PC dan alat telah terhubung (probe test) dengan baik, jika tidak terhubung memeriksa kembali alat, aki dan konektor.

j. Pada menu bar setting di software geores, pilih metode wennersclumberger.

k. Masukkan nilai berdasarkan konfigurasi yang dipilih, selanjutnya arus listrik di injeksi ke dalam tanah untuk mendapatkan nilai resistivitas, setelah arus listrik sudah di injeksi ke dalam tanah maka akan keluar nilai data pada software geores yang terdapat dalam laptop.

1. Save editing.

m. Pada menu bar resistivity atur tempat penyimpanan data.

n. Kemudian pilih start untuk memulai akuisisi data.

o. Setelah selesai save data.

p. Lakukan proses pengambilan data yang sama untuk pengukuran sesudah pemompaan.
3. Pengolahan data.

Pengolahan data menggunakan software res2dinv. Data yang dimasukkan adalah data hasil pengukuran lapangan. Hasil pengolahannya berupa data souding data hasil pengukuran lapangan. Hasil pengolahannya berupa data souding yaitu ketebalan lapisan, kedalaman, dan nilai resistivitas.

a. Prosedur pengolahan data di excel

1. Memasukkan data hasil ke dalam Ms.Excel dalam hal ini nilai arus dan nilai beda potensial.

2. Menghitung faktor geometri (k) Konfigurasi wenner-sclumberger dengan rumus faktor geometri yaitu $K=\pi n(n+1) a$

3. Menghitung resistivitas semu (R) dimana rumus resistivitas semu adalah $\rho=\frac{\Delta \mathrm{V}}{\mathrm{I}} \mathrm{K}$.

4. Memindahkan data hasil resistivitas semu ke notepad sesuai dengan format yang ada pada software Res2Dinv.

b. Prosedur pengolahan data dengan Res2Dinv

1. Masukkan data resistivitas semu ( $\rho s)$ hasil perhitungan, data datum point (dp), dan spasi elektoda (a) ke notepad yang disimpan dalam format file*.dat, Adapun penjelasan dari tiap line pada notepad sebagai berikut:

1.a. Line 1 adalah nama survey.

1.b. Line 2 adalah spasi terkecil yang digunakan.

1.c. Line 3 adalah jenis susunan konfigurasi yang digunakan (wenner-sclumberger $=7$ ).

1.d. Line 4 adalah jumlah total data pengukuran (datum point).

1.e. Line 5 adalah tipe dari lokasi untuk datum point. ketik angka 1 karena datum point diketahui.

1.f. Line 6 ketik 0 untuk data resistivitasi.

1.g. Line 7 adalah memasukkan data pengukuran dan perhitungan nilai datum point, spasi terkecil, dan 
ISSN: 1979-7362

nilai resistivitas semu yang diperoleh dari perhitungan (ditulis berurutan).

1.h. Line 8 . Ketik 0 yang terdiri dari 4 line.

2. Untuk membuat model penampang geolistrik resistivitas 2D konfigurasi wenner-sclumberger menggunakan software Res2Dinv

3. Kemudian klik file $\rightarrow$ read data file $\rightarrow$ pilih data file sebelumnya telah disimpan dalam bentuk *.dat

4. Selanjutnya melakukan inversi dengan metode least-square dengan cara klik inversion least-squares inversion, maka akan muncul hasil inversi software Res2Dinv.

5. Lakukan langkah pengolahan yang sama untuk menghasilkan penampang resistivitas 2D pada pengukuran sesudah pemompaan.

c. Pengukuran Pemompaan.

Dalam proses pemompaan dilakukan pengambilan data untuk mencari nilai debit dan volume dengan parameter perhitungan:

$$
\begin{aligned}
& \text { Debit: } Q=\frac{v}{t} \\
& \text { Volume: } V=Q . t
\end{aligned}
$$

d. Pengujian Permeabilitas Tanah Dan Porositas

Dalam pengujian permeabilitas tanah dan porositas tanah dilakukan pengambilan sampel tanah sebanyak 3 kali dengan kedalaman yang berbeda tiap sampelnya, pada pengujian sampel tanah permeabilitas metode yang digunakan yaitu falling head dengan persamaan KT $=\left[\frac{a . L}{A \cdot t}\right] \ln \left[\frac{h 1}{h f}\right]$ dan pada pengujian sampel tanah untuk mengetahui nilai porositasnya menggunakan persamaan $\mathrm{n}$ $=\frac{V v}{V s} 100 \%$.

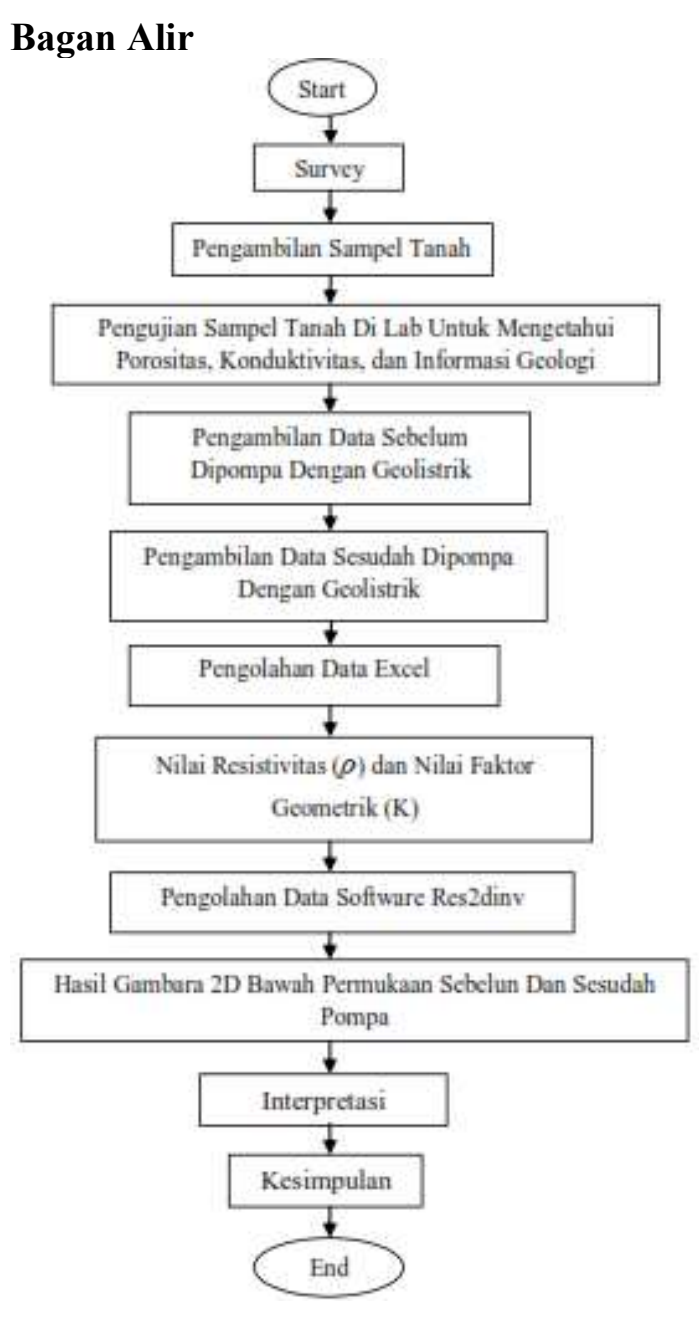

\section{HASIL DAN PEMBAHASAN}

\section{Lintasan Pengukuran}

Kabupaten Takalar merupakan salah satu wilayah kabupaten di Provinsi Sulawesi Selatan yang terletak pada bagian selatan. Dapat dilihat pada gambar peta geologi takalar di atas menunjukkan letak titik koordinat suatu lintasan pada saat pengambilan data. Titik koordinat pada lintasan pertama di titik pertama berada pada 5'24'6" lintang selatan dan $119^{\circ} 26^{\prime} 30^{\prime \prime}$ bujur timur kemudian pada titik kedua berada pada $5^{\circ} 24^{\prime} 8^{\prime \prime}$ lintang selatan dan 119'26’32” bujur timur. 


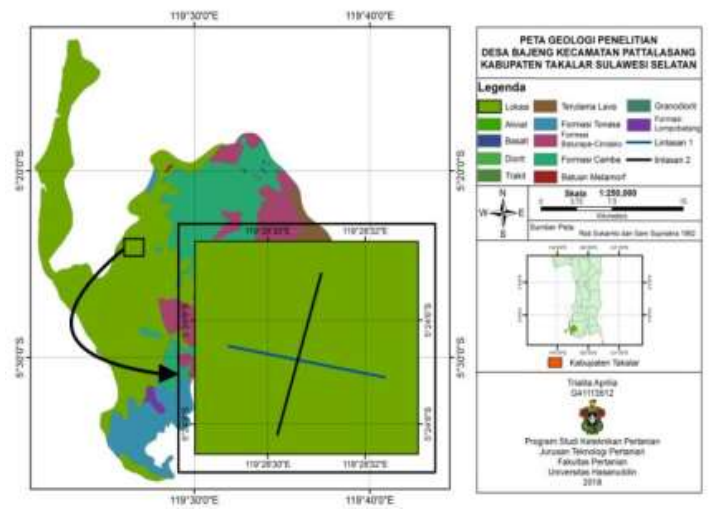

Gambar 2. Peta Geologi Takalar dan Skema Pengukuran Data.

Selanjutnya titik koordinat pada lintasan kedua di titik pertama berada pada 5'24'6" lintang selatan dan 119'26'32" bujur timur kemudian pada titik kedua berada pada $5^{\circ} 24^{\prime} 8^{\prime \prime}$ lintang selatan dan $119^{\circ} 26^{\prime} 30^{\prime \prime}$ bujur timur. Pada peta geologi takalar memiliki nilai skala 1: 250,000, kemudian dapat dilihat didalam kolom legenda terdapat beberapa macam formasi yang dapat berpengaruh di daerah takalar, formasi tersebut antara lain:

a. Formasi Tonasa (Temt) terdiri dari batugamping pejal dan berlapis, koral, bioklastik, kalkarenit, dengan sisipan napal, batugamping pasiran dengan umur berkisar dari Eosen sampai Miosen tengah.

b. Formasi Camba (Tmc) terdiri dari batuan sedimen laut berselingan dengan batuan gunung api, batu pasir tufaan berselingan dengan tufa, batu pasir dan batu lmpung bersisipan napal, batu gamping, konglomerat, breksi gunungapi, dan batubara.

c. Batu Gunungapi Baturappe - cindako (Tpbv) terjadi secara setempat terdiri dari lava dan breksi bersusunan basal dengan sisipan sedikit tufa dan konglomerat, umumnya batuan didominasi oleh lava (Tpbl) berumur Pliosen Akhir.

d. Formasi Lompobattang (Qlv) terdiri dari aglomerat lava, breksi, endapan lahar, dan tufa. e. Endapan Aluvial dan pantai adalah sedimen termuda yang merupakan endapan rawa dan endapan sungai yang terdiri dari material lepas dan tersebar mengikuti sungai di sepanjang lembah maupun pantai. Endapan ini juga terdiri atas krikil, pasir, lanau, lumpur, lempung dan batu gamping koral.

f. Batuan Terobasan Andesit atau trakhit $(\mathrm{a} / \mathrm{b})$ berupa retas dan stok menerobos batuan gamping Formasi Camba (Tmcv) dan batuan gunungapi BaturappeCindako (Tpbv).

Namun dari berbagai macam formasi diatas yang dapat berpengaruh di daerah takalar, pada lokasi tempat penelitian yang diambil, formasi yang terdapat hanyalah endapan alivial, dimana endapan ini merupakan endapan rawa dan endapan sungai yang terdiri dari material lepas dan tersebar mengikuti sungai disepanjang lembah maupun pantai, dan terdiri juga atas krikil, pasir, lanau, lumpur, lempung dan batugamping koral.

\section{Karakteristik Sumur Dangkal}

Adapun beberapa parameter perhitungan yang digunakan dalam pembahasan karakteristik sumur dangkal, diantaranya seperti pengukuran debit, pengukuran volume, pengukuran tinggi muka air tanah, pengujian konduktivitas hidrolik dan pengujian porositas tanah.

\section{Debit Dan Volume}

Adapun tabel data pengukuran debit, volume, dan pengukuran data tinggi muka air tanah pada saat pengukuran pertama, kedua, dan ketiga: 
a. Debit

Tabel 1. hasil data pengukuran debit setelah diolah.

\begin{tabular}{ccc}
\hline No & Pengukuran & Q \\
\hline $\mathbf{1}$ & Pengukuran & 0,91 liter/dtk \\
& 1 & \\
$\mathbf{2}$ & Pengukuran & 1,79 liter/dtk \\
& 2 & \\
$\mathbf{3}$ & Pengukuran & 1,95 liter/detik \\
& 3 & \\
\hline
\end{tabular}

b. Volume

Tabel 2. hasil data pengukuran volume setelah diolah.

\begin{tabular}{ccccc}
\hline No & Pengukuran & T & Q & V \\
\hline $\mathbf{1}$ & Pengukuran & 21.600 & 0,91 & 19,656 \\
& 1 & & & liter/detik \\
$\mathbf{2}$ & Pengukuran & 21.600 & 1,79 & 38,664 \\
& 2 & & & liter/detik \\
3 & $\begin{array}{c}\text { Pengukuran } \\
\text { 3 } 21.600\end{array}$ & 1,96 & 42,336 \\
& & & liter/detik \\
\hline
\end{tabular}

\section{Porositas dan konduktivitas hidrolik}

Adapun tabel data pengujian tiga sampel tanah yang digunakan dalam pengujian porositas dan konduktivitas hidrolik:

a. Pengujian porositas

Tabel 3. data sampel tanah pengujian porositas setelah diolah.

\begin{tabular}{cccc}
\hline No & Sampel 1 & Sampel 2 & Sampel 3 \\
\hline $\mathbf{1}$ & $\mathrm{n}=$ & $\mathrm{n}=$ & $\mathrm{n}=45,83 \%$ \\
& $48,94 \%$ & $49,94 \%$ & \\
& & & Rata-rata: \\
& & & $48,23 \%$ \\
\hline
\end{tabular}

b. Pengujian konduktivitas hidrolik

Tabel 4. data sampel tanah pengujian konduktivitas hidrolik setelah diolah.

\begin{tabular}{cccc}
\hline No & Sampel 1 & Sampel 2 & Sampel 3 \\
\hline $\mathbf{1}$ & $\mathrm{KT}=$ & $\mathrm{KT}=$ & $\mathrm{KT}=$ \\
& 0,000155 & 0,000168 & 0,000148 \\
& $\mathrm{~cm} /$ detik & $\mathrm{cm} /$ detik & cm/detik \\
& & & Rata-rata: \\
& & & 0,000157 \\
& & & $\mathrm{~cm} /$ detik \\
\hline
\end{tabular}

Pengukuran Profil Lapisan Dengan Metode geolistrik

Dalam menginterpretasi suatu data, pendugaan jumlah lapisan geologi dapat ditentukan berdasarkan skala warna atau pengelompokkan warna yang masingmasing memiliki nilai rentang resistivitas, sehinggah kita dapat mengetahui jenis material yang terkandung dengan mencocokkan hasil inversi tersebut dengan tabel nilai resistivitas (Wijaya, 2015). Berikut disajikan tabel nilai resistivitas untuk masing-masing material dibumi.

Tabel 5. Nilai resistivitas material bumi beserta bahan dan fluida.

\begin{tabular}{cc}
\hline Material & $\begin{array}{l}\text { Resistivitas } \\
(\mathbf{\Omega m})\end{array}$ \\
\hline Air (Udarah) & 0 \\
\hline Sandstones (Batu Pasir) & $200-8000$ \\
\hline Sand (Pasir) & $1-1000$ \\
Clay (Lempung) & $1-100$ \\
Andesite (Andesit) & $1,7 \times 10-2-$ \\
& $45 \times 104$ \\
Ground Water (Air Tanah) & $0,5-300$ \\
Sea Water (Air Asin) & 0.2 \\
Dry Water (Kerikil Kering) & $600-10000$ \\
Alluvium (Aluvium) & $10-800$ \\
Gravel (Krikil) & $100-600$ \\
\\
\hline \\
\hline
\end{tabular}

\section{Pengukuran 1}

Lintasan 1 (sebelum dipompa)

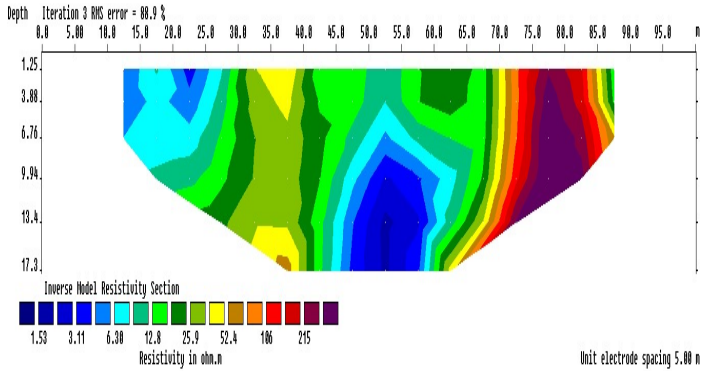


Lintasan 1 (sesudah dipompa)

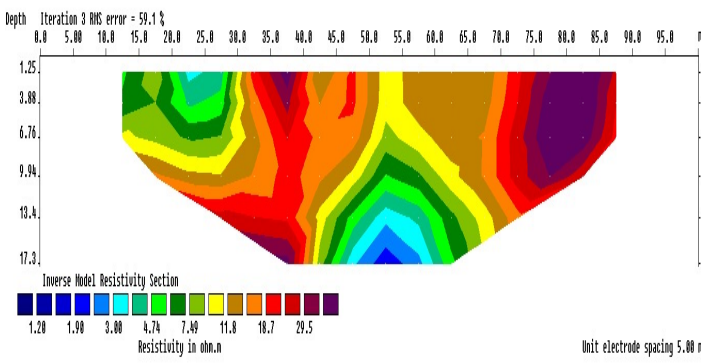

Gambar 3. Profil resistivitas pengukuran 1 lintasan 1 sebelum dan sesudah di pompa.

Nilai resistivitas pada lintasan 1 sebelum dipompa yang diperoleh dari pengolahan data memiliki nilai dari 1,53 $215 \Omega \mathrm{m}$ dan kesalahan iterasinya $88.9 \%$, sedangkan pada lintasan 1 sesudah pemompaan mempunyai nilai resistivitas dari $1,20-29,5 \Omega m$ dan kesalahan iterasinya $59,1 \%$ sesuai pada gambar 16 . Pada lintasan 1 sebelum dan sesudah di pompa dimana terdapat luasan yang berpotensi air berada pada kelompok atau skala warna biru dimana kedua lintasan pada skala warna biru merupakan lapisan yang mudah diloloskan oleh air karena memiliki nilai resistivitas yang lebih rendah di bandingkan dengan skala warna hijau dan skala warna merah.

Sehingga dengan memperhatikan dan menganalisa variasi gambar penampang profil resistivitas, maka terdapat tabel interpretasi data sebagai berikut:

Tabel 6. Interpretasi data pengukuran 1 lintasan 1 sebelum dan sesudah pemompaan.

\begin{tabular}{cccccc}
\hline & \multicolumn{2}{c}{ Nilai } & \multicolumn{2}{c}{ Material } \\
Resistivitas & & \\
\hline & Sebelum & Sesudah & Sebelum & Sesudah \\
& $(\boldsymbol{\Omega m})$ & $(\boldsymbol{\Omega m})$ & & \\
Biru & $1,53-$ & $1,20-$ & Clay & Clay \\
& 6,30 & 3,00 & & \\
Hijau & $12,8-$ & $4,74-$ & Clay & Clay \\
& 52,4 & 11,8 & & \\
Merah & $106-$ & $18,7-$ & Alluvium & Clay \\
& 215 & 29,5 & & \\
\hline
\end{tabular}

Dari Tabel 7, maka dapat di simpulkan bahwa pada lintasan 1 sebelum di pompa material yang di dapatkan yaitu material clay dan alluvium, sedang sesudah di pompa material yang di dapatkan yaitu material clay.

Lintasan 2 (sebelum dipompa)
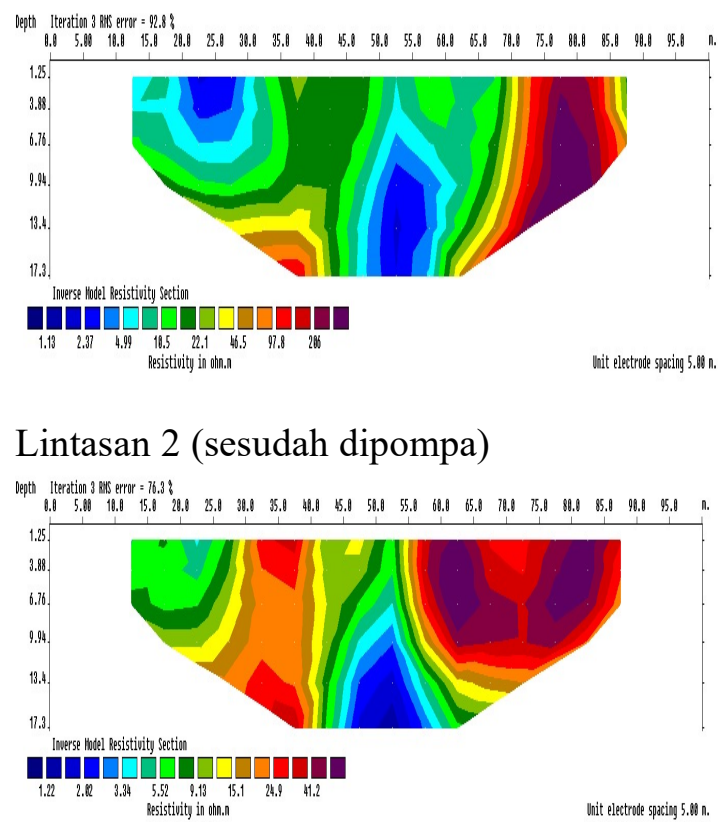

Gambar 4. Profil resistivitas pengukuran 1 lintasan 2 sebelum dan sesudah di pompa.

Nilai resistivitas pada lintasan 2 sebelum dipompa yang diperoleh dari pengolahan data memiliki nilai dari 1,13 $206 \Omega \mathrm{m}$ dan kesalahan iterasinya $92,8 \%$, sedangkan pada lintasan 2 sesudah pemompaan mempunyai nilai resistivitas dari $1,22-41,2 \Omega \mathrm{m}$ dan kesalahan iterasinya $76,3 \%$ sesuai pada gambar 17 . Pada lintasan 2 sebelum dan sesudah di pompa dimana terdapat luasan yang berpotensi air berada pada kelompok atau skala warna biru dimana kedua lintasan pada skala warna biru merupakan lapisan yang mudah diloloskan oleh air karena memiliki nilai resistivitas yang lebih rendah di bandingkan dengan skala warna hijau dan skala warna merah.

Sehingga dengan memperhatikan dan menganalisa variasi gambar penampang 
profil resistivitas, maka terdapat tabel interpretasi data sebagai berikut:

Tabel 7. Interpretasi data pengukuran 1 lintasan 2 sebelum dan sesudah pemompaan.

\begin{tabular}{cccccc}
\hline Warna & \multicolumn{2}{c}{ Nilai Resistivitas } & \multicolumn{2}{c}{ Material } \\
\hline \multirow{4}{*}{ Biru } & Sebelum & \multicolumn{2}{c}{ Sesudah Sebelum } & Sesudah \\
& $(\boldsymbol{\Omega m})$ & $(\boldsymbol{\Omega m})$ & & \\
& $1,13-$ & $1,22-$ & Clay & Clay \\
Hijau & 4,99 & 3,34 & & \\
& $10,5-$ & $5,52-$ & Clay & Clay \\
Merah & 46,5 & 15,1 & & \\
& $97,8-$ & $24,9-$ & Alluvium & Clay \\
& 206 & 41,2 & & \\
\hline
\end{tabular}

Dari Tabel 7, maka dapat di simpulkan bahwa pada lintasan 2 sebelum di pompa material yang di dapatkan yaitu material clay dan alluvium, sedang sesudah di pompa material yang di dapatkan yaitu material clay.

\section{Pengukuran 2}

Lintasan 1 (sebelum pompa)

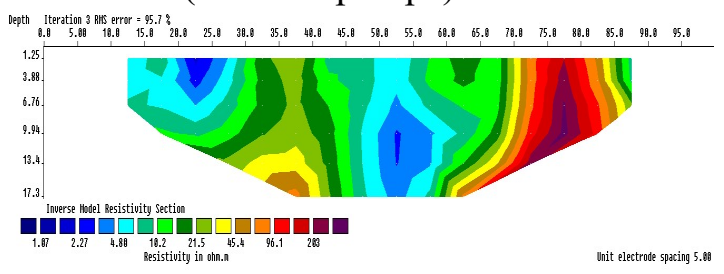

Lintasan 1 (sesudah pompa)

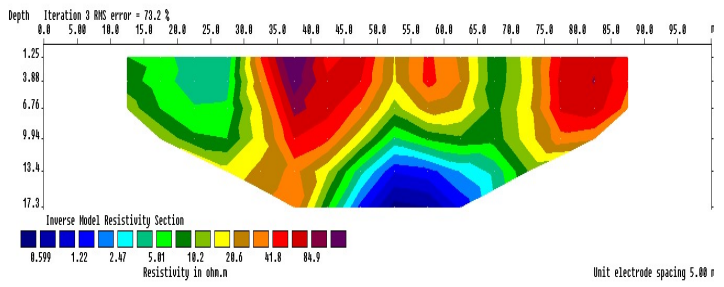

Gambar 5. Profil resistivitas pengukuran 2 lintasan 1 sebelum dan sesudah di pompa.

Nilai resistivitas pada lintasan 1 sebelum dipompa yang diperoleh dari pengolahan data memiliki nilai dari 1,07 $203 \Omega \mathrm{m}$ dan kesalahan iterasinya $95,7 \%$, sedangkan pada lintasan 1 sesudah pemompaan mempunyai nilai resistivitas dari $0,599-84,9 \Omega \mathrm{m}$ dan kesalahan iterasinya 73,2 \% sesuai pada gambar 18 . Pada lintasan 1 sebelum di pompa dimana terdapat luasan yang berpotensi air berada pada kelompok atau skala warna biru dimana kedua lintasan pada skala warna biru merupakan lapisan yang mudah diloloskan oleh air karena memiliki nilai resistivitas yang lebih rendah di bandingkan dengan skala warna hijau dan skala warna merah.

Sehingga dengan memperhatikan dan menganalisa variasi gambar penampang profil resistivitas, maka terdapat tabel interpretasi data sebagai berikut:

Tabel 8. Interpretasi data pengukuran 2 lintasan 1 sebelum dan sesudah pemompaan.

\begin{tabular}{ccccc}
\hline Warna & \multicolumn{2}{c}{ Nilai Resistivitas } & \multicolumn{2}{c}{ Material } \\
\hline \multirow{4}{*}{ Biru } & Sebelum & Sesudah & Sebelum & Sesudah \\
& $(\boldsymbol{\Omega})$ & $(\mathbf{\Omega m})$ & & \\
& $1,07-$ & 0,599 & Clay & Ground \\
Hijau & 4,80 & $-2,47$ & & water \\
& $10,5-$ & $5,52-$ & Clay & Clay \\
Merah & 46,5 & 15,1 & & \\
& $97,8-$ & $24,9-$ & Alluvium & Clay \\
& 206 & 41,2 & & \\
\hline
\end{tabular}

Dari Tabel 8, maka dapat di simpulkan bahwa pada lintasan 1 sebelum di pompa material yang di dapatkan yaitu material clay dan alluvium, sedang sesudah di pompa material yang di dapatkan yaitu material ground water atau air tanah dan clay.

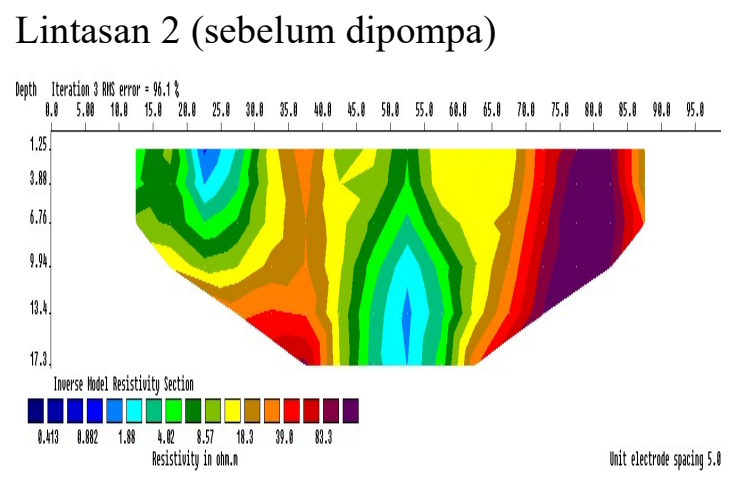

Lintasan 2 (sesudah dipompa) 


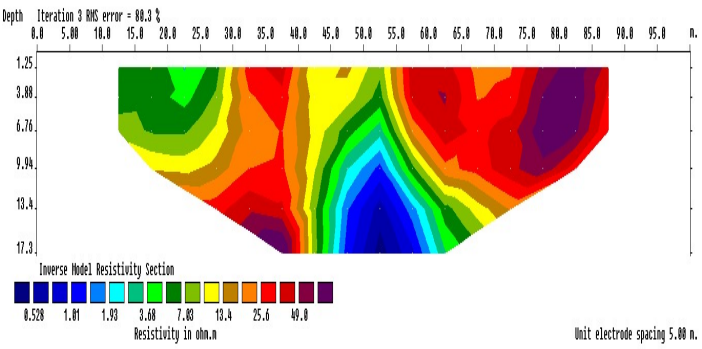

Gambar 6. Profil resistivitas pengukuran 2 lintasan 2 sebelum dan sesudah di pompa.

Nilai resistivitas pada lintasan 2 sebelum dipompa yang diperoleh dari pengolahan data memiliki nilai dari $0,413-$ $83,3 \Omega \mathrm{m}$ dan kesalahan iterasinya $96,1 \%$, sedangkan pada lintasan 2 sesudah pemompaan mempunyai nilai resistivitas dari 0,528 - 49,0 $\Omega \mathrm{m}$ dan kesalahan iterasinya 80,3\% sesuai pada gambar 19 . Pada lintasan 2 sebelum di pompa dimana terdapat luasan yang berpotensi air berada pada kelompok atau skala warna biru dimana kedua lintasan pada skala warna biru merupakan lapisan yang mudah diloloskan oleh air karena memiliki nilai resistivitas yang lebih rendah di bandingkan dengan skala warna hijau dan skala warna merah.

Sehingga dengan memperhatikan dan menganalisa variasi gambar penampang profil resistivitas, maka terdapat tabel interpretasi data sebagai berikut:

Tabel 9. Interpretasi data pengukuran 2 lintasan 2 sebelum dan sesudah pemompaan.

\begin{tabular}{cccccc}
\hline Warna & \multicolumn{2}{c}{ Nilai Resistivitas } & \multicolumn{2}{c}{ Material } \\
\hline & $\begin{array}{l}\text { Sebelum } \\
(\boldsymbol{\Omega m})\end{array}$ & $\begin{array}{l}\text { Sesudah Sebelum } \\
(\boldsymbol{\Omega m})\end{array}$ & Sesudah \\
Biru & $0,413-$ & 0,528 & Ground & Ground \\
& 1,88 & $-49,0$ & water & water \\
Hijau & $4,02-$ & $3,68-$ & Clay & Clay \\
& 18,3 & 13,4 & & \\
Merah & $39,0-$ & $25,6-$ & Clay & Clay \\
& 83,3 & 49,0 & & \\
\hline
\end{tabular}

Dari Tabel 9, maka dapat di simpulkan bahwa pada lintasan 2 sebelum di pompa material yang di dapatkan yaitu material air tanah atau ground water dan clay, sedang sesudah di pompa material yang di dapatkan yaitu material ground water atau air tanah dan clay.

\section{Pengukuran 3}

Lintasan 1 (sebelum dipompa)

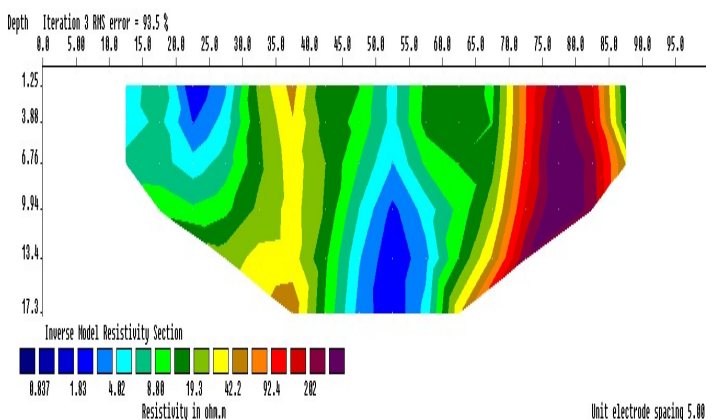

Lintasan 1 (sesudah dipompa)

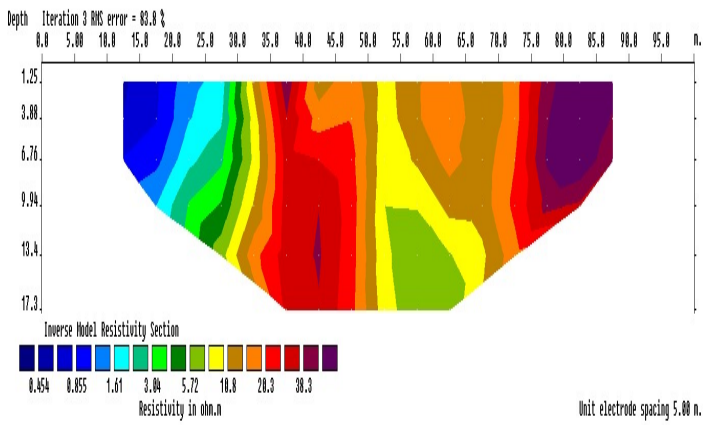

Gambar 7. Profil resistivitas pengukuran 3 lintasan 1 sebelum dan sesudah di pompa.

Nilai resistivitas pada lintasan 1 sebelum dipompa yang diperoleh dari pengolahan data memiliki nilai dari 0,837 $202 \Omega \mathrm{m}$ dan kesalahan iterasinya 93,5 \%, sedangkan pada lintasan 1 sesudah pemompaan mempunyai nilai resistivitas dari 0,454 - 38,3 $\Omega \mathrm{m}$ dan kesalahan iterasinya 73,2\% sesuai pada gambar 20 . Pada lintasan 1 sebelum di pompa dimana terdapat luasan yang berpotensi air berada pada kelompok atau skala warna biru dimana kedua lintasan pada skala warna biru merupakan lapisan yang mudah diloloskan oleh air karena memiliki nilai resistivitas yang lebih rendah di bandingkan dengan skala warna hijau dan skala warna merah.

Sehingga dengan memperhatikan dan menganalisa variasi gambar penampang 
profil resistivitas, maka terdapat tabel interpretasi data sebagai berikut:

Tabel 10. Interpretasi data pengukuran 3 lintasan 1 sebelum dan sesudah pemompaan.

\begin{tabular}{cccccc}
\hline Warna & \multicolumn{2}{c}{ Nilai Resistivitas } & \multicolumn{2}{c}{ Material } \\
\hline \multirow{4}{*}{ Biru } & $\begin{array}{l}\text { Sebelum } \\
(\boldsymbol{\Omega} \mathbf{m})\end{array}$ & $\begin{array}{l}\text { Sesudah } \\
(\boldsymbol{\Omega m})\end{array}$ & Sebelum & Sesudah \\
& $0,837-$ & 0,454 & Ground & Ground \\
Hijau & 4,02 & $-38,3$ & water & water \\
& $8,80-$ & $3,04-$ & Clay & Clay \\
Merah & 42,2 & 10,8 & & \\
& $92,4-$ & $20,3-$ & Alluvium & Clay \\
& 202 & 38,3 & & \\
\hline
\end{tabular}

Dari Tabel 10, maka dapat di simpulkan bahwa pada lintasan 1 sebelum di pompa material yang di dapatkan yaitu material air tanah atau ground water, clay dan alluvium, sedang sesudah di pompa material yang di dapatkan yaitu material ground water atau air tanah dan clay.

Lintasan 2 (sebelum dipompa)

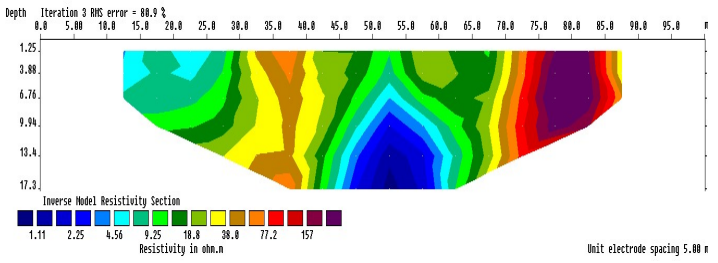

Lintasan 2 (sesudah dipompa)

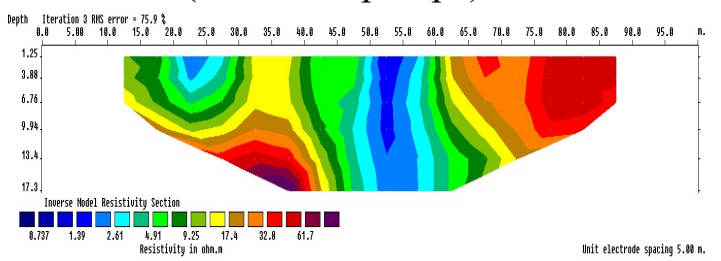

Gambar 8. Profil resistivitas pengukuran 3 lintasan 2 sebelum dan sesudah di pompa.

Nilai resistivitas pada lintasan 2 sebelum dipompa yang diperoleh dari pengolahan data memiliki nilai dari 1,11$157 \Omega \mathrm{m}$ dan kesalahan iterasinya $80,9 \%$, sedangkan pada lintasan 2 sesudah pemompaan mempunyai nilai resistivitas dari 0,737 - 61,7 $\Omega \mathrm{m}$ dan kesalahan iterasinya $75,9 \%$ sesuai pada gambar 21 . Pada lintasan 2 sebelum di pompa dimana terdapat luasan yang berpotensi air berada pada kelompok atau skala warna biru dimana kedua lintasan pada skala warna biru merupakan lapisan yang mudah diloloskan oleh air karena memiliki nilai resistivitas yang lebih rendah di bandingkan dengan skala warna hijau dan skala warna merah.

Sehingga dengan memperhatikan dan menganalisa variasi gambar penampang profil resistivitas, maka terdapat tabel interpretasi data sebagai berikut:

Tabel 11. Interpretasi data pengukuran 3 lintasan 2 sebelum dan sesudah pemompaan.

\begin{tabular}{|c|c|c|c|c|}
\hline \multirow{2}{*}{$\begin{array}{c}\text { Warn } \\
\text { a } \\
\end{array}$} & \multicolumn{2}{|c|}{ Nilai Resistivitas } & \multicolumn{2}{|c|}{ Material } \\
\hline & $\begin{array}{l}\text { Sebelu } \\
\text { m }(\Omega \mathrm{m})\end{array}$ & $\begin{array}{l}\text { Sesuda } \\
\text { h }(\Omega \mathrm{m})\end{array}$ & $\begin{array}{c}\text { Sebelu } \\
\mathrm{m}\end{array}$ & $\begin{array}{c}\text { Sesuda } \\
h\end{array}$ \\
\hline Biru & $\begin{array}{c}1,11- \\
4,56\end{array}$ & $\begin{array}{c}0,737 \\
-2,61\end{array}$ & Clay & $\begin{array}{l}\text { Ground } \\
\text { water }\end{array}$ \\
\hline Hijau & $\begin{array}{c}9,25- \\
38,0\end{array}$ & $\begin{array}{c}4,91- \\
17,4\end{array}$ & Clay & Clay \\
\hline Merah & $\begin{array}{c}77,2- \\
157\end{array}$ & $\begin{array}{c}32,8- \\
61,7\end{array}$ & Alluvium & Clay \\
\hline
\end{tabular}

Dari Tabel 11, maka dapat di simpulkan bahwa pada lintasan 1 sebelum di pompa material yang di dapatkan yaitu material clay dan alluvium, sedang sesudah di pompa material yang di dapatkan yaitu material ground water atau air tanah dan clay.

\section{Luas penampan dan perubahan posisi kedalaman}

Dari gambar profil resistivitas dapat di lihat luasan penampang perubahan warna secara keseluruhan beserta perubahan kedalaman potensi air setiap lintasan yang ada pada pengukuran pertama, kedua, dan ketiga sebelum dan sesudah di pompa 


\section{a. Lintasan 1}

\section{Pengukuran 1}

Tabel 12. Pengukuran luas penampang dan perubahan kedalaman potensi air pada lintasan 1 pengukuran 1 .

\begin{tabular}{|l|l|c|c|l|l|}
\hline No & Warna & L.penampang Perubahan warna & Perubahan Kedalaman \\
\hline & & $\begin{array}{c}\text { L. sebelum } \\
\text { Pompa }\end{array}$ & $\begin{array}{c}\text { L. sesudah } \\
\text { Pompa }\end{array}$ & Sebelum & Sesudah \\
\hline 1 & Biru & $363,22 \mathrm{~m}^{2}$ & $31,2 \mathrm{~m}^{2}$ & $3,88 \mathrm{~m}$ & $13,4 \mathrm{~m}$ \\
\hline 2 & Hijau & $480,69 \mathrm{~m}^{2}$ & $402,93 \mathrm{~m}^{2}$ & $1,25 \mathrm{~m}$ & $3,88 \mathrm{~m}$ \\
\hline 3 & Merah & $71,63 \mathrm{~m}^{2}$ & $323,88 \mathrm{~m}^{2}$ & $1,25 \mathrm{~m}$ & $1,25 \mathrm{~m}$ \\
\hline
\end{tabular}

Pada skala warna biru pada pengukuran 1 lintasan 1 sebelum di pompa nilai luasannya yaitu $363,22 \mathrm{~m}^{2}$, dan setelah di pompa nilai luasannya menjadi $31,20 \mathrm{~m}^{2}$, hal ini menyebabkan luasan setelah di pompa bertambah, dimana daerah pada skala warna biru merupakan daerah yang dapat meloloskan air karena memiliki pori atau rongga tanah yang lebih besar, sehinggah daerah tersebut merupakan daerah yang diduga berpotensi air dimana potensi air tanah sangat berpengaruh dengan adanya pori dan permeabilitas tanah, dengan nilai resistivitas yang lebih rendah atau kurang dibandingkan dengan skala warna hijau dan merah. Volume air pada daerah yang berpotensi air pada skala warna biru sebelum di pompa yaitu $17.518,10 \mathrm{~m}^{3} / 1$ setelah di pompa menjadi $1.504,77 \mathrm{~m}^{3} / 1$, dengan kedalaman sebelum di pompa yaitu $3,88 \mathrm{~m}$, dan setelah di pompa yaitu $13,40 \mathrm{~m}$.

Pada skala warna hijau pada pengukuran 1 lintasan 1 sebelum di pompa nilai luasannya yaitu $480,69 \mathrm{~m}^{2}$, dan setelah di pompa nilai luasannya menjadi 402,93 $\mathrm{m}^{2}$, hal ini menyebabkan luasan setelah di pompa berkurang, dimana daerah pada skala warna hijau merupakan daerah yang dapat meloloskan air, namun air yang lolos tidak sama seperti daerah pada sekala warna biru, dimana pori atau rongga tanah yang terdapat pada skala warna hijau lebih padat yang memiliki nilai resistivitas yang lebih besar dibandingkan skala warna biru, dimana kedalaman sebelum di pompa yaitu 1,25 m, dan sesudah di pompa yaitu 3,88 m. Pada skala warna merah pada pengukuran 1 lintasan 1 sebelum di pompa nilai luasannya yaitu $71,63 \mathrm{~m}^{2}$, dan setelah di pompa nilai luasannya menjadi 323,88 $\mathrm{m}^{2}$, hal ini menyebabkan luasan setelah di pompa bertambah, dimana daerah pada warna merah merupakan daerah yang sulit meloloskan air karena memiliki pori atau rongga tanah yang sangat padat, dengan nilai resistivitas yang lebih besar dibandingkan skala warna biru dan hijau, dimana kedalaman sebelum dipompa yaitu $1,25 \mathrm{~m}$, dan setelah di pompa menjadi 1,25 $\mathrm{m}$.

\section{Pengukuran 2}

Tabel 13. Pengukuran luas penampang dan perubahan kedalaman potensi air pada lintasan 1 pengukuran 2 .

\begin{tabular}{|l|c|c|c|c|c|}
\hline No & Warna & \multicolumn{2}{|c|}{ L.penampang Perubahan warna } & Perubahan Kedalaman \\
\hline & & $\begin{array}{c}\text { L. sebelum } \\
\text { Pompa }\end{array}$ & $\begin{array}{c}\text { L. sesudah } \\
\text { Pompa }\end{array}$ & Sebelum & Sesudah \\
\hline 1 & Biru & $205,06 \mathrm{~m}^{2}$ & $147,2 \mathrm{~m}^{2}$ & $1,25 \mathrm{~m}$ & $9,94 \mathrm{~m}$ \\
\hline 2 & Hijau & $626,48 \mathrm{~m}^{2}$ & $514,0 \mathrm{~m}^{2}$ & $1,25 \mathrm{~m}$ & $6,76 \mathrm{~m}$ \\
\hline 3 & Merah & $66,12 \mathrm{~m}^{2}$ & $236,74 \mathrm{~m}^{2}$ & $1,25 \mathrm{~m}$ & $1,25 \mathrm{~m}$ \\
\hline
\end{tabular}

Pada skala warna biru pada pengukuran 2 lintasan 1 sebelum di pompa nilai luasannya yaitu $205,06 \mathrm{~m}^{2}$, dan setelah di pompa nilai luasannya menjadi 147,20 $\mathrm{m}^{2}$, hal ini menyebabkan luasan setelah di pompa bertambah, dimana daerah pada skala warna biru merupakan daerah yang dapat meloloskan air karena memiliki pori atau rongga tanah yang lebih besar, sehinggah daerah tersebut merupakan daerah yang diduga berpotensi air dimana potensi air tanah sangat berpengaruh dengan adanya pori dan permeabilitas tanah, dengan nilai resistivitas yang lebih rendah atau kurang dibandingkan dengan skala warna hijau dan merah. Volume air pada daerah yang berpotensi air pada skala warna biru sebelum di pompa yaitu $9.890,04 \mathrm{~m}^{3} / 1$ setelah di pompa menjadi $7.099,45 \mathrm{~m}^{3} / 1$, dengan kedalaman sebelum 
di pompa yaitu $1,25 \mathrm{~m}$, dan setelah di pompa yaitu 9,94 m.

Pada skala warna hijau pada pengukuran 2 lintasan 1 sebelum di pompa nilai luasannya yaitu $624,48 \mathrm{~m}^{2}$, dan setelah di pompa nilai luasannya menjadi 514,00 $\mathrm{m}^{2}$, hal ini menyebabkan luasan setelah di pompa berkurang, dimana daerah pada skala warna hijau merupakan daerah yang dapat meloloskan air, namun air yang lolos tidak sama seperti daerah pada sekala warna biru, dimana pori atau rongga tanah yang terdapat pada skala warna hijau lebih padat yang memiliki nilai resistivitas yang lebih besar dibandingkan skala warna biru, dimana kedalaman sebelum di pompa yaitu 1,25 m, dan sesudah di pompa yaitu 9,94 m.

Pada skala warna merah pada pengukuran 2 lintasan 1 sebelum di pompa nilai luasannya yaitu $66,12 \mathrm{~m}^{2}$, dan setelah di pompa nilai luasannya menjadi 236,74 $\mathrm{m}^{2}$, hal ini menyebabkan luasan setelah di pompa bertambah, dimana daerah pada warna merah merupakan daerah yang sulit meloloskan air karena memiliki pori atau rongga tanah yang sangat padat, dengan nilai resistivitas yang lebih besar dibandingkan skala warna biru dan hijau, dimana kedalaman sebelum dipompa yaitu $1,25 \mathrm{~m}$, dan setelah di pompa menjadi 1,25 $\mathrm{m}$.

\section{Pengukuran 3}

Tabel 14. Pengukuran luas penampang da perubahan kedalaman potensi air pada lintasan pengukuran 3.

\begin{tabular}{|l|l|c|c|c|c|}
\hline No & Warna & $\begin{array}{c}\text { L.penampang } \\
\text { L. sebelum } \\
\text { Pompa }\end{array}$ & $\begin{array}{c}\text { L. sesudah } \\
\text { Pompa }\end{array}$ & Sebelum & Sesudah \\
\hline 1 & Biru & $215,6 \mathrm{~m}^{2}$ & $139,04 \mathrm{~m}^{2}$ & $1,25 \mathrm{~m}$ & $\begin{array}{r}\text { Tidak } \\
\text { terdeteksi }\end{array}$ \\
\hline 2 & Hijau & $497,55 \mathrm{~m}^{2}$ & $381,75 \mathrm{~m}^{2}$ & $1,25 \mathrm{~m}$ & $6,76 \mathrm{~m}$ \\
\hline 3 & Merah & $82,65 \mathrm{~m}^{2}$ & $355,98 \mathrm{~m}^{2}$ & $1,25 \mathrm{~m}$ & $1,25 \mathrm{~m}$ \\
\hline
\end{tabular}

Pada skala warna biru pada pengukuran 3 lintasan 1 sebelum di pompa nilai luasannya yaitu $215,60 \mathrm{~m}^{2}$, dan setelah di pompa nilai luasannya menjadi 139,04 $\mathrm{m}^{2}$, hal ini menyebabkan luasan setelah di pompa bertambah, dimana daerah pada skala warna biru merupakan daerah yang dapat meloloskan air karena memiliki pori atau rongga tanah yang lebih besar, sehinggah daerah tersebut merupakan daerah yang diduga berpotensi air dimana potensi air tanah sangat berpengaruh dengan adanya pori dan permeabilitas tanah, dengan nilai resistivitas yang lebih rendah atau kurang dibandingkan dengan skala warna hijau dan merah. Volume air pada daerah yang berpotensi air pada skala warna biru sebelum di pompa yaitu $10.398,38 \mathrm{~m}^{3} / 1$ setelah di pompa menjadi $6.705,89 \mathrm{~m}^{3} / 1$, dengan kedalaman sebelum di pompa yaitu $1,25 \mathrm{~m}$, dan setelah di pompa yaitu tidak terdeteksi.

Pada skala warna hijau pada pengukuran 3 lintasan 1 sebelum di pompa nilai luasannya yaitu $497,55 \mathrm{~m}^{2}$, dan setelah di pompa nilai luasannya menjadi 381,75 $\mathrm{m}^{2}$, hal ini menyebabkan luasan setelah di pompa berkurang, dimana daerah pada skala warna hijau merupakan daerah yang dapat meloloskan air, namun air yang lolos tidak sama seperti daerah pada sekala warna biru, dimana pori atau rongga tanah yang terdapat pada skala warna hijau lebih padat yang memiliki nilai resistivitas yang lebih besar dibandingkan skala warna biru, dimana kedalaman sebelum di pompa yaitu 1,25 m, dan sesudah di pompa yaitu 9,94 m.

Pada skala warna merah pada pengukuran 3 lintasan 1 sebelum di pompa nilai luasannya yaitu $82,65 \mathrm{~m}^{2}$, dan setelah di pompa nilai luasannya menjadi 355,98 $\mathrm{m}^{2}$, hal ini menyebabkan luasan setelah di pompa bertambah, dimana daerah pada warna merah merupakan daerah yang sulit meloloskan air karena memiliki pori atau rongga tanah yang sangat padat, dengan nilai resistivitas yang lebih besar dibandingkan skala warna biru dan hijau, dimana kedalaman sebelum dipompa yaitu $1,25 \mathrm{~m}$, dan setelah di pompa menjadi 1,25 $\mathrm{m}$. 


\section{b. Lintasan 2}

\section{Pengukuran 1}

Tabel 15. Pengukuran luas penampang dan perubahan kedalaman potensi air pada lintasan 2 pengukuran 1 .

\begin{tabular}{|l|l|l|l|l|l|}
\hline $\begin{array}{l}\mathbf{N} \\
\mathbf{0}\end{array}$ & $\begin{array}{l}\text { War } \\
\text { na }\end{array}$ & \multicolumn{2}{l|}{$\begin{array}{l}\text { L.penampang } \\
\text { perubahan warna }\end{array}$} & \multicolumn{2}{l|}{$\begin{array}{l}\text { Perubahan } \\
\text { Kedalaman }\end{array}$} \\
\hline & & $\begin{array}{c}\text { L.sebelum } \\
\text { pompa }\end{array}$ & $\begin{array}{c}\text { L. } \\
\text { sesudah } \\
\text { pompa }\end{array}$ & & \\
\hline 1 & Biru & $317,89 \mathrm{~m}^{2}$ & $105,40 \mathrm{~m}^{2}$ & $1,25 \mathrm{~m}$ & $6,76 \mathrm{~m}$ \\
\hline 2 & Hijau & $520,77 \mathrm{~m}^{2}$ & $230,38 \mathrm{~m}^{2}$ & $1,25 \mathrm{~m}$ & $1,25 \mathrm{~m}$ \\
\hline 3 & Merah & $77,14 \mathrm{~m}^{2}$ & $181,83 \mathrm{~m}^{2}$ & $1,25 \mathrm{~m}$ & $1,25 \mathrm{~m}$ \\
\hline \multicolumn{7}{|c}{} \\
\hline
\end{tabular}

pengukuran 1 lintasan 2 sebelum di pompa nilai luasannya yaitu $317,89 \mathrm{~m}^{2}$, dan setelah di pompa nilai luasannya menjadi 105,40 $\mathrm{m}^{2}$, hal ini menyebabkan luasan setelah di pompa berkurang, dimana daerah pada skala warna biru merupakan daerah yang dapat meloloskan air karena memiliki pori atau rongga tanah yang lebih besar, sehinggah daerah tersebut merupakan daerah yang diduga berpotensi air dimana potensi air tanah sangat berpengaruh dengan adanya pori dan permeabilitas tanah, dengan nilai resistivitas yang lebih rendah atau kurang dibandingkan dengan skala warna hijau dan merah. Volume air pada daerah yang berpotensi air pada skala warna biru sebelum di pompa yaitu $15.331,83 \mathrm{~m}^{3} / 1$ setelah di pompa menjadi $5.083,44 \mathrm{~m}^{3} / 1$, dengan kedalaman sebelum di pompa yaitu $1,25 \mathrm{~m}$, dan setelah di pompa yaitu $6,76 \mathrm{~m}$.

Pada skala warna hijau pada pengukuran 1 lintasan 2 sebelum di pompa nilai luasannya yaitu $520,77 \mathrm{~m}^{2}$, dan setelah di pompa nilai luasannya menjadi 230,38 $\mathrm{m}^{2}$, hal ini menyebabkan luasan setelah di pompa berkurang, dimana daerah pada skala warna hijau merupakan daerah yang dapat meloloskan air, namun air yang lolos tidak sama seperti daerah pada sekala warna biru, dimana pori atau rongga tanah yang terdapat pada skala warna hijau lebih padat yang memiliki nilai resistivitas yang lebih besar dibandingkan skala warna biru, dimana kedalaman sebelum di pompa yaitu $1,25 \mathrm{~m}$, dan sesudah di pompa yaitu $1,25 \mathrm{~m}$. Pada skala warna merah pada pengukuran 1 lintasan 2 sebelum di pompa nilai luasannya yaitu $77,14 \mathrm{~m}^{2}$, dan setelah di pompa nilai luasannya menjadi 181,83 $\mathrm{m}^{2}$, hal ini menyebabkan luasan setelah di pompa bertambah, dimana daerah pada warna merah merupakan daerah yang sulit meloloskan air karena memiliki pori atau rongga tanah yang sangat padat, dengan nilai resistivitas yang lebih besar dibandingkan skala warna biru dan hijau, dimana kedalaman sebelum dipompa yaitu $1,25 \mathrm{~m}$, dan setelah di pompa menjadi 1,25 $\mathrm{m}$.

\section{Pengukuran 2}

Tabel 16. Pengukuran luas penampang dan perubahan kedalaman potensi air pada lintasan 2 pengukuran 2 .

\begin{tabular}{|c|c|c|c|c|c|}
\hline No & $\begin{array}{l}\text { Warn } \\
\text { a }\end{array}$ & $\begin{array}{l}\text { L.penampang } \\
\text { warna }\end{array}$ & \multicolumn{2}{|c|}{ perubahan } & \multicolumn{2}{|l|}{$\begin{array}{l}\text { Perubahan } \\
\text { Kedalaman }\end{array}$} \\
\hline & & $\begin{array}{c}\text { L.sebelum } \\
\text { pompa }\end{array}$ & $\begin{array}{c}\text { L. sesudah } \\
\text { pompa }\end{array}$ & & \\
\hline 1 & Biru & $81,65 \mathrm{~m}^{2}$ & $105,40 \mathrm{~m}^{2}$ & $6,76 \mathrm{~m}$ & $6,76 \mathrm{~m}$ \\
\hline 2 & $\begin{array}{c}\text { Hija } \\
\mathrm{u}\end{array}$ & $758,01 \mathrm{~m}^{2}$ & $230,38 \mathrm{~m}^{2}$ & $1,25 \mathrm{~m}$ & $1,25 \mathrm{~m}$ \\
\hline 3 & Merah & $145,98 \mathrm{~m}^{2}$ & $342,33 \mathrm{~m}^{2}$ & $1,25 \mathrm{~m}$ & $1,25 \mathrm{~m}$ \\
\hline
\end{tabular}

Pada skala warna biru pada pengukuran 2 lintasan 2 sebelum di pompa nilai luasannya yaitu $81,65 \mathrm{~m}^{2}$, dan setelah di pompa nilai luasannya menjadi 105,40 $\mathrm{m}^{2}$, hal ini menyebabkan luasan setelah di pompa bertambah, dimana daerah pada skala warna biru merupakan daerah yang dapat meloloskan air karena memiliki pori atau rongga tanah yang lebih besar, sehinggah daerah tersebut merupakan daerah yang diduga berpotensi air dimana potensi air tanah sangat berpengaruh dengan adanya pori dan permeabilitas tanah, dengan nilai resistivitas yang lebih rendah atau kurang dibandingkan dengan skala warna hijau dan merah. Volume air pada daerah yang berpotensi air pada skala warna biru sebelum di pompa yaitu $3.937,97 \mathrm{~m}^{3} / 1$ setelah di pompa menjadi $5.083,44 \mathrm{~m}^{3} / 1$, dengan kedalaman sebelum 
di pompa yaitu $6,76 \mathrm{~m}$, dan setelah di pompa yaitu $6,76 \mathrm{~m}$.

Pada skala warna hijau pada pengukuran 2 lintasan 2 sebelum di pompa nilai luasannya yaitu $758,01 \mathrm{~m}^{2}$, dan setelah di pompa nilai luasannya menjadi 230,38 $\mathrm{m}^{2}$, hal ini menyebabkan luasan setelah di pompa berkurang, dimana daerah pada skala warna hijau merupakan daerah yang dapat meloloskan air, namun air yang lolos tidak sama seperti daerah pada sekala warna biru, dimana pori atau rongga tanah yang terdapat pada skala warna hijau lebih padat yang memiliki nilai resistivitas yang lebih besar dibandingkan skala warna biru, dimana kedalaman sebelum di pompa yaitu $1,25 \mathrm{~m}$, dan sesudah di pompa yaitu 1,25 $\mathrm{m}$.

Pada skala warna merah pada pengukuran 2 lintasan 2 sebelum di pompa nilai luasannya yaitu $145,98 \mathrm{~m}^{2}$, dan setelah di pompa nilai luasannya menjadi 342,33 $\mathrm{m}^{2}$, hal ini menyebabkan luasan setelah di pompa bertambah, dimana daerah pada warna merah merupakan daerah yang sulit meloloskan air karena memiliki pori atau rongga tanah yang sangat padat, dengan nilai resistivitas yang lebih besar dibandingkan skala warna biru dan hijau, dimana kedalaman sebelum dipompa yaitu $1,25 \mathrm{~m}$, dan setelah di pompa menjadi 1,25 $\mathrm{m}$.

\section{Pengukuran 3}

Tabel 17. Pengukuran luas penampang dan perubahan kedalaman potensi air pada lintasan 2 pengukuran 3.

\begin{tabular}{|l|l|l|c|c|c|}
\hline $\begin{array}{l}\mathbf{N} \\
\mathbf{0}\end{array}$ & $\begin{array}{l}\text { Warn } \\
\text { a }\end{array}$ & \multicolumn{2}{|l|}{$\begin{array}{l}\text { L.penampang perubahan } \\
\text { warna }\end{array}$} & \multicolumn{2}{|l|}{$\begin{array}{l}\text { Perubahan } \\
\text { Kedalaman }\end{array}$} \\
\hline & & $\begin{array}{c}\text { L.sebelum } \\
\text { pompa }\end{array}$ & $\begin{array}{c}\text { L. } \\
\text { sesudah } \\
\text { pompa }\end{array}$ & & \\
\hline 1 & Biru & $201,45 \mathrm{~m}^{2}$ & $148,81 \mathrm{~m}^{2}$ & $3,88 \mathrm{~m}$ & $1,25 \mathrm{~m}$ \\
\hline 2 & Hijau & $553,05 \mathrm{~m}^{2}$ & $480,18 \mathrm{~m}^{2}$ & $1,25 \mathrm{~m}$ & $1,25 \mathrm{~m}$ \\
\hline 3 & Merah & $82,65 \mathrm{~m}^{2}$ & $147,2 \mathrm{~m}^{2}$ & $1,25 \mathrm{~m}$ & $1,25 \mathrm{~m}$ \\
\hline
\end{tabular}

Pada skala warna biru pada pengukuran 3 lintasan 2 sebelum di pompa nilai luasannya yaitu $201,45 \mathrm{~m}^{2}$, dan setelah di pompa nilai luasannya menjadi 148,81 $\mathrm{m}^{2}$, hal ini menyebabkan luasan setelah di pompa bertambah, dimana daerah pada skala warna biru merupakan daerah yang dapat meloloskan air karena memiliki pori atau rongga tanah yang lebih besar, sehinggah daerah tersebut merupakan daerah yang diduga berpotensi air dimana potensi air tanah sangat berpengaruh dengan adanya pori dan permeabilitas tanah, dengan nilai resistivitas yang lebih rendah atau kurang dibandingkan dengan skala warna hijau dan merah. Volume air pada daerah yang berpotensi air pada skala warna biru sebelum di pompa yaitu $9.715,93 \mathrm{~m}^{3} / 1$ setelah di pompa menjadi $7.177,10 \mathrm{~m}^{3} / 1$, dengan kedalaman sebelum di pompa yaitu $3,88 \mathrm{~m}$, dan setelah di pompa yaitu $1,25 \mathrm{~m}$.

Pada skala warna hijau pada pengukuran 3 lintasan 2 sebelum di pompa nilai luasannya yaitu $553,05 \mathrm{~m}^{2}$, dan setelah di pompa nilai luasannya menjadi 480,18 $\mathrm{m}^{2}$, hal ini menyebabkan luasan setelah di pompa berkurang, dimana daerah pada skala warna hijau merupakan daerah yang dapat meloloskan air, namun air yang lolos tidak sama seperti daerah pada sekala warna biru, dimana pori atau rongga tanah yang terdapat pada skala warna hijau lebih padat yang memiliki nilai resistivitas yang lebih besar dibandingkan skala warna biru, dimana kedalaman sebelum di pompa yaitu $1,25 \mathrm{~m}$, dan sesudah di pompa yaitu $1,25 \mathrm{~m}$.

Pada skala warna merah pada pengukuran 3 lintasan 2 sebelum di pompa nilai luasannya yaitu $82,65 \mathrm{~m}^{2}$, dan setelah di pompa nilai luasannya menjadi $147,2 \mathrm{~m}^{2}$, hal ini menyebabkan luasan setelah di pompa bertambah, dimana daerah pada warna merah merupakan daerah yang sulit meloloskan air karena memiliki pori atau rongga tanah yang sangat padat, dengan nilai resistivitas yang lebih besar dibandingkan skala warna biru dan hijau, dimana kedalaman sebelum dipompa yaitu $1,25 \mathrm{~m}$, dan setelah di pompa menjadi 1,25 


\section{PENUTUP}

\section{Kesimpulan}

Adapun kesimpulan yang didapatkan pada penelitian ini yaitu:

1. Pada pengukuran pertama sampai pengukuran ketiga sebelum dan sesudah pemompaan di sepanjang lintasan pengambilan data bawah permukaan tanah, material bumi yang didapatkan hanyalah material clay atau lempung, air tanah, dan alluvium.

2. Keberaadan material clay atau lempung berada direntang nilai resistivitas kurang lebih dari $1-100 \Omega \mathrm{m}$, keberadaan material air tanah berada direntang nilai resistivitas sangat rendah yaitu kurang lebih dari 0,5-300 $\Omega \mathrm{m}$, dan keberadaan material alluviumberada direntang nilai resistivitas kurang lebih dari $10-800$ $\Omega \mathrm{m}$.

\section{Saran}

Perlu melakukan handboring atau coreboring untuk mendapatkan karakteristik porositas tanah yang lebih dalam lagi agar hasil yang didapatkan lebih maksimal.

\section{DAFTAR PUSTAKA}

Ayu, Ieke Wulan., Sugeng Prijono., Soemarno. 2013. Elevasi Ketersediaan Air Tanah Kering di Kecamatan Unter Wes Sumbawa Besar. Fakultas Pertanian. Universitas Samawa.

Bernas, Sitti Masreah., Robianto, Hendro, Soesanto., Satria, Jayapriatna., Momon, Sodiq Imanuddin., Bahri. 2015. Penuntun Praktikum Fisika Tanah. Fakultas Pertanian. Universitas Sriwijaya.

DeGroot, Headlin, C., Constable, S. 1990. Occam's Inversion to Generate Smooth, Two-Dimensional Model From Magnetote Iluric Data. Geophysich, 55, 1613-1624.

Djarwanti, Noegroho. 2008. Komparasi Koefisien Permeabilitas (k) pada Tanah
Kohesif. Fakultas Teknik. Universitas Sebelas Maret.

Edwards, L.S. 1977. A Modified Pseudosection For Resistivity amd Induced-Polarization. Geophysics, 42, 1020-1036.

Ghozali, Agung Syufi. 2012., Suki Maryanto., fajar Rahmanto. 2014. Aplikasi Metode Geolistrik Resistivitas Konfigurasi Wenner untuk Memetakan Pola Sebaran Permukaan Tanah di Jombok, Kecamatan Ngantang, Kabupaten Malang. Universitas Jember: Malang.

Griffiths D.H., Barker, R.D. 1993. Twodimensional resistivity imaging and modelling in areas of complex geology journal of applied geophyysics, 29, 211-226

Halik, Gusfan., Jojok Widodo S. 2008. Pendugaan Poteni Air Tanah Dengan Metode Geolistrik Konfigurasi Sclumberger di Kampus Tegal Boto Universitas Jember. Universitas jember: Jember.

Hanfiah, Kemas Ali. 2005. Dasar-Dasar Ilmu Tanah. Jakarta: Raja Grafindo Persada.

Sakka. 2001. Metoda Geolistrik Tahanan Jenis. Fakultas Maatematika dan Ilmu Pengetahuan Alam. Universitas Hasanuddin: Makassar.

Simaremare, Saroha. 2015. Analisis Aliran Air Tanah Satu Dimensi (Kajian Laboratorium). Fakultas Teknik. Universitas Sriwijaya.

Susanto, Rachman. 2009. Dasar-dasar Ilmu Tanah. Yogyakarta: Kanisius.

Telford. W.M.., Sheriff, R.E., Geldart, L.P.1990. Applied Geophysics 2ed. Cambridge University Press: New York.

Wijaya, Andrias Sanggra. 2015. Aplikasi Metode Geolistrik Resistivitas Konfigurasi Wenner Untuk Menentukan Struktur Tanah Di Halaman Belakang SCC ITS Surabaya. Institut Teknologi Sepulu November. Surabaya. 